\title{
Suriye ve Ukrayna Krizleri Çerçevesinde ABD Rusya İlişkileri
}

\author{
Ahmet GÜLER ${ }^{l}$
}

Öz

Sovyetler Birliği'nin dağılması ve Rusya'nın uluslararası sistemde tekrardan aktif rol almaya başlaması Soğuk Savaş dönemi gibi olmasa da Rusya ve ABD'yi krizler çerçevesinde sık sık karşı karşıya getirmiştir. Çalışmada ilk olarak Rusya'nın yakın coğrafyası olarak adlandırdığı bölgenin içerisinde yer alan, Ukrayna'da yaşanılan kriz ve Rusya'nın Kırım'ı işgali çerçevesinde Rusya ve ABD'nin bölgedeki politikaları ve rekabeti ele alınmaya çalışılacaktır. Ardından uluslararası sistemi derinden etkileyen Arap Baharı'nın son halkası olarak karşımıza çıkan Suriye Krizi Rusya ve ABD perspektifinden incelenecektir. Demokratikleşme taleplerine rejimin verdiği sert tepkiyle birlikte bir iç savaş gibi gözüken Suriye Krizi kısa zamanda çok aktörlü bir uluslararası krize dönmüştür. Bu çerçevede krizin önemli aktörleri olan ABD ve Rusya tarafindan Suriye'nin önemi ele alınıp, Suriye Krizi çerçevesinde Rusya ve ABD politikaları ve rekabeti ele alınmaya çalışılacaktır.

Anahtar Kelimeler: Ukrayna Krizi, Kırım İşgali, Suriye Krizi, ABD Rusya Rekabeti

\section{USA-Russia Relations In The Framework Of Syrian and Ukraine Crisis}

\begin{abstract}
With the collapse of the Soviet Union and the active participation of Russia in the international system has often caused Russia and the USA to confront as a part of crisis, not like the Cold War. In the present study, the policies and competition of Russia and the USA will be studied within the framework of the crisis in Ukraine and Russia's occupation of Crimea. Then, the Syrian crisis which was the last part of Arab Spring has deeply effected the international system will be examined from the perspective of Russia and the USA. This crisis which seemed to be a civil war as a result of the reaction of the regime to democratization demands turned into a multi-participant international crisis. Within this framework, the importance of Syria will be discussed from the point of USA and Russia that are important actors of crisis. İn addition the policies and competition of Russia and the USA will be studied considering Syrian Crisis.
\end{abstract}

Key Words: Ukraine Crisis, Crimea, Syria Crisis, Rivalry between USA and Russia

\footnotetext{
${ }^{1}$ Tezli Yüksek Lisans Öğrencisi, Uludağ Üniversitesi, Sosyal Bilimler Enstitüsü, Uluslararası İlişkiler Bölümü, e-posta: ahmet-guler35@hotmail.com
} 


\section{Giriş}

Sovyetler Birliği’nin dağılması ile ABD'nin hegemon güç olarak yer aldığı tek kutuplu bir sistem ortaya çıkmıştı. Rusya'nın 2008 Gürcistan müdahalesine kadar geçen süreç içerisinde, Rusya ABD’nin tek kutuplu düzenine karşı herhangi bir direniş gösterememiştir. Bu süreçte Yakın Çevre Doktrinini ilan etmiş ve bu çerçevede özellikle eski Sovyet coğrafyasında tekrardan hâkim güç konumuna gelmeye çalışmıştır. ABD ise bu dönemde dünya jandarmalığı rolünü üstlenmiş ve dünyada meydana gelen krizlere karşı tek başına müdahale etme eğiliminde olmuştur.

Her ne kadar 11 Eylül saldırıları ile ABD’nin tek kutuplu dünya düzeni sona erdi tartışmaları yaşansa da, ABD’nin tek kutuplu dünya düzenine en ciddi başkaldırı 2007 Münih Güvenlik Konferansı sırasında Rusya Devlet Başkanı V. Putin tarafından gerçekleştirilmiştir. 08.08.2008 yılında Rusya’nın Gürcistan'a orantısız güç kullanarak girmesi uluslararası sistemde etkin bir güç olarak kendisinin de yer aldığının ilanı olmuştur. Bu sürece gelinirken gerçekleşen Turuncu Devrimler ve Rusya'nın yakın coğrafyasındaki ülkelerde Batı yanlısı rejimlerin kurulması çabaları, Rusya tarafından çevrelendiği hissini uyandırmış ve Rusya Gürcistan müdahalesi ile buna izin vermeyeceğini göstermiştir.

Rusya daha henüz uluslararası arenada aktif rol almaya başlamadan önce, ABD eski Sovyet coğrafyasında Batılı kurumlarla birlikte etki kurma çabasına girişmişti. Bu doğrultuda Ukrayna ve Gürcistan gibi devletlerin AB ve NATO üyelikleri gündeme getirildi. Rusya'nın petrol fiyatlarındaki artış ile kendini toparlamaya başlaması ve dünya arenasına tekrardan çıkışı ile birlikte Soğuk Savaş döneminin kutup liderleri arasında tekrardan büyük bir rekabet başlamış oluyordu. Bu dönemi, Soğuk Savaş döneminden ayıran en önemli farklılığı dünyada iki kutuplu bir sistem yerine yavaş yavaş birçok güç merkezinin olduğu bir sisteme geçilmesi oluşturmaktaydı.

Rusya ve ABD arasındaki ilk ciddi sorun 2013 yılında Ukrayna'da başlayan halk hareketlenmesi ile yaşanmıştır. Yanukoviç’in $\mathrm{AB}$ ile ortaklık antlaşmasını imzalamayacağını bildirmesi üzerine başlayan protesto gösterileri kısa bir sürede uluslararası krize dönüştü. Bu süreçte Rusya ülkedeki Rus yanlılarını ve özellikle Ukrayna'nın doğusundaki ayrılıkçı hareketi desteklemiştir. ABD ise Yanukoviç'in iktidarının değişmesini memnuniyetle karşılamıştır. Poroşenko'nun iktidara gelmesi üzerine Rusya'nın tepkisi sert olmuş ve Ukrayna krizinin Batı tarafından oluşturulduğu dile getirilmiştir. Rusya'nın, Rus azınlığı bahane ederek Kırım'ı ilhak etmesi ABD ile ilişkilerini iyice geren nokta olmuştur.

ABD'nin Afganistan ve Irak işgalleri sırasında büyük maliyetler yüklenmesi ve karşısında bu defa uluslararası sistemin önemli güçlerinden olan Rusya'nın yer alması direkt müdahale konusunun seçenekler arasında yer almamasına neden oldu. Bu dönemde ABD olaylara temkinli yaklaşmış ve uluslararası kurumlarla birlikte Rusya'ya karşı yaptırım kararlarının alınmasında öncülük etmiştir.

Bu dönemde iki devlet arasındaki ilişkiler Suriye Krizi’nin de devam etmesi ve iki devletin de krize müdahil olmasıyla birlikte gergin olarak seyretmeye devam etmiştir. 2010 yılında başlayan Arap 
Baharı Suriye'ye sıçramış ve bölgedeki nüfuz kurma mücadelesinde önemli bir yeri olan Suriye iki devlet arasındaki yeni rekabet alanını oluşturmuştur. Krizin ilk yıllarında ABD Esad'sız bir yönetimi tercih etmiş, fakat zamanla bu kararından geri adım atmıştır. Rusya ise baştan beri Esad'lı çözümün savunucusu olmuştur.

Ortadoğu Soğuk Savaş döneminde Sovyetler Birliği ve ABD arasında önemli nüfuz kurma mücadelelerinin yaşandığı bir coğrafyaydı. Soğuk Savaş sonrası dönemde Rusya'nın tekrardan uluslararası sisteme dâhil olması, Ortadoğu üzerinden nüfuz mücadelelerinin iki devlet arasında tekrardan yaşanmaya başlamasına neden olmuştur.

Bu çalışmada ilk olarak Ukrayna krizi perspektifinden Rusya ve ABD arasındaki rekabet ele alınacaktır. Rusya ve ABD açısından Ukrayna ve Kırım'ın, bu doğrultuda Karadeniz'in taşıdığı önem belirtildikten sonra krize karşı aldıkları tavır aktarılacaktır. Ardından Arap Baharı'nda zincirin son halkasını oluşturan Suriye krizi yine aynı çerçeveden incelenmeye çalışılacaktır. Öncelikle Suriye'nin ve doğal olarak Ortadoğu'nun ABD ve Rusya açısından taşıdığı önem üstünde durulacak, ardından kriz çerçevesinde iki ülkenin izlediği politikalar ele alınacaktır.

\section{Ukrayna Krizi ve Kırım'ın İlhakı}

Soğuk Savaş'ın sona ermesinden sonra eski Sovyet ülkeleri bağımsızlıklarını ilan etmeye başlarken, Ukrayna’nın bağımsızlık süreci diğer Sovyet ülkelerinden farklı olarak gerçeklemiş ve halkoyuna sunulmuştur. Aralık 1991'de gerçekleştirilen referandum ile bu karar yüzde 90'ın üzerinde bir oyla kabul edilmiştir. 24 Ağustos 1991'de Ukrayna Yüksek Kurulu tarafından Ukrayna'nın bağımsızlığı ilan edilmiştir (Büyükakıncı 2004: 405). 8 Aralık 1991'de Rusya, Ukrayna ve Belarus liderleri yaptıkları bir toplantıda "Minsk Antlaşması" ile Bağımsız Devletler Topluluğu'nu (BDT) kurmuş ve Rusya Federasyonu, kendisini SSCB'nin halefi ilan etmiştir (Özel 2015: 76). Ukrayna'nın, Bağımsız Devletler Topluluğu'nda ki isteksiz tavrı ve AB ve NATO ile ilişkilerini geliştirme hamleleri Rusya'nın, bölgede Batının etkisini artıırmasına ilişsin korkularını tetiklemiştir.

Soğuk Savaş'ın sona ermesiyle birlikte Batılı ülkeler ve Batılı ülkelerin ağırlığı bulunan kurumların eski Sovyet coğrafyası ile yakın ilişkiler geliştirme çabası temel olarak, Rusya'nın askeri olarak sınırlandırılmasını, Hazar ve Orta Asya enerji kaynakları üzerinden enerji kartının elinden alınmasını hedeflemiştir (Sağlam 2014: 443). Her ne kadar Rusya Sovyetler Birliği’nin dağılmasından sonra bir bunalım sürecine girmiş olsa da Batılı devletler Sovyetlerin en önemli halefi konumundaki Rusya'nın tekrardan eski Sovyet coğrafyasında etkili bir aktör olarak yer almasını ve yeni bir bloklaşma ihtimalinin doğmasını istememekteydi. Bu çerçevede Gürcistan, Ukrayna, Kırgızistan'da renkli devrimlerle birlikte bu ülkelerde iktidara Batı yanlısı isimlerin gelmesi, genel olarak ABD ve AB'nin Rusya hamlesi olarak görülmüştür (Sağlam 2014: 443).

Rusya Federasyonu, Sovyetler Birliği'nin dağılmasıyla Soğuk Savaş'ın sona ermesinin ardından uluslararası sistemde güç dengesinin kendi aleyhinde gelişmesi nedeniyle eski Sovyet ülkelerine karşı 
Yakın Çevre Doktrinini geliştirmeye başlamıştır. Rusya kendisini güneyden çeviren bu devletlerin oluşturduğu coğrafyayı dış politikasının en öncelikli etki alanı olarak tanımlamış, bu bölgelerdeki her türlü gelişmeden birinci derece sorumlu olduğunu iddia etmiştir (Mikail 2007: 254). Rusya'nın Yakın Çevre Doktrini ile temel amacını, eski Sovyet coğrafyasında ABD önderliğindeki Batılıların bölgede aktif olmasını engellemek ve Soğuk Savaş dönemindeki gibi çevrelenmeye karşı önlem alabilmek oluşturmaktaydı.

\section{Ukrayna ve Kırım'ın Rusya Açısından Önemi}

Rusya açısından Ukrayna diğer eski Sovyet cumhuriyetlerinden daha farklı bir anlam taşımaktaydı. Rusların tarih sahnesine Kiev'de çıkmış olması Ukrayna'nın Rusya açısından önemini artıran önemli bir faktördür. Rusya açısından baktığımızda Ukrayna'yı önemli kılan birçok jeopolitik faktörde yer almaktadır. Rusya Soğuk Savaş sonrası girdiği bunalımdan hidrokarbon kaynaklarının ihracı ile çıkmış ve hidrokarbon kaynaklarının ihracı uluslararası politikada tekrardan aktif olabilmesinin temelini oluşturmuştur. Rus ekonomisinin hidrokarbon kaynaklarının ihracına aşırı bağımlı olması ve kırılgan bir ekonomiye sahip olması nedeniyle Ukrayna jeopolitiği Rusya açısından son derece önemlidir. Ukrayna'nın enerji naklinde transit geçiş koridoru oluşturması (Keskin 2014: 4749) Rusya açısından Ukrayna’yı vazgeçilmez kılmaktadır. Rusya'nın Avrupa'ya doğalgaz ihracatının yaklaşık yüzde 80’i Ukrayna üzerinden geçmektedir (Özel 2015: 81). Rusya'nın Karadeniz donanmasının Ukrayna'nın Kırım bölgesinde bulunması bu ülkenin Rusya tarafından önemini arttıran en önemli etkenlerden bir diğeridir (Keskin 2014: 47-49).

Ukrayna jeopolitik konumu açısından Avrasya ile Avrupa arasında tampon bölge olma özelliği taşır. Rus donanmasının tarihsel olarak konuşlandığı Karadeniz'deki Sivastopol Limanı Akdeniz'e inmek için ve Karadeniz'de hâkimiyet kurabilme açısından son derece kritik öneme sahiptir. Ayrıca Ukrayna'nın Rusya ile en uzun doğu sınırına sahip olması, Rusya'yı dengelemek isteyen ABD başta olmak üzere Batılı güçler için Ukrayna’yı cazip bir yer kılarken, Rusya'nın da yumuşak karnı haline getirmektedir (Sağlam 2014: 440).

ABD eski ulusal güvenlik danışmanlarından Brezezinski "Büyük Satranç Tahtası" adlı eserinde Rusya için Ukrayna olmadan bir imparatorluk olamayacağını ve Asyalı bir devlet olarak kalacağını belirterek Rusya açısından Ukrayna'nın ne kadar önemli olduğunu ortaya koymuştur (Brzezinski 2005: 79).

\section{Ukrayna ve Kırım'ın ABD Açısından Önemi}

ABD başta olmak üzere Batılı devletler açısından Hazar ve Orta Asya'daki gaz ve petrollerin alternatif yollarla Avrupa'ya ulaştırılmasında Ukrayna çok önemli bir güzergâh olma özelliği taşır. Avrupa Birliği açısından baktığımızda Rusya ile ticari ilişkilerde enerji tüm AB ithalatının \%25 'ini oluştururken Rusya'nın enerji ticaretindeki payı ise üçte iki oranındadır. Gazın \%50 'si ve petrolün \%30’u ise Rusya'dan karşılanmaktadır (Ünal 2011: 117). ABD açısından Ukrayna'nın Batı dünyası ile 
entegrasyonunun sağlanması Rusya'nın Batıyla bağlantı noktasını kesecek ve hem Avrupa'nın güvenliği açısından olumlu olacaktır hem de Rusya'yı doğuya yani karaya sıkıştırma açısından olumlu olacaktır. ABD bundan dolayı özellikle Gürcistan ve Ukrayna'yı Batı blokuna dâhil etmek ve Rusya'yı çevreleyebilmek adına bu iki ülkenin NATO üyeliğini gündeme getirmiştir. ABD açısından Batılı değerlere sahip ve Batı ile entegre olmuş Ukrayna, Rusya'nın Karadeniz'de etkinliğinin sınırlandırılması açısından da çok önemli bir yere sahiptir.

\section{Krizin Seyri ve ABD Rusya İlişkileri}

Dolayısıyla Ukrayna'nın ABD ve Rusya açısından önemini inceledikten sonra 23 Kasım 2013'te Ukrayna'nın devlet başkanı Yanukoviç tarafından AB ile 2010'da paraf edilen ortaklık antlaşmasını imzalamayacağını açıklaması (Mearsheimer 2014: 5) üzerine Kiev'de başlayan toplumsal eylemlerin neden uluslararası bir krize dönüştüğünü daha iyi anlayabiliriz. Kiev meydanında toplanan Batı Ukraynalılar, ülkelerinin geleceklerinin Batı ile yani AB ve NATO gibi Batılı kurumlarla işbirliğinden geçtiğini savunurken, özellikle Ukrayna'nın doğusundaki halk Rusya ile yakınlaşmanın gelecekleri açısından daha faydalı olduğunu savunmaktaydılar.

Krizin başlangıcında hem Batı dünyası ve ABD hem de Rusya temkinli bir tavır takınmaya çalışmıştır. NATO, Avrupa Birliği ve Amerika Birleşik Devletleri ülkedeki şiddet olaylarını sadece kınamış ve taraflara diyalog çağrısında bulunmuştur (Erol 2014: 5).

Kiev'de başlayan bu protestoların Ukrayna geneline yayılmasıyla birlikte ilk olarak hükümet istifa etmiş ardından Yanukoviç devrilmiş (Harvard IOP Policy Brief 2014: 4) Batı yanlısı Poroşenko iktidara gelmiştir. Poroşenko'nun askıya alınan Ortaklık Anlaşmasını imzalaması ve Batı yanlısı bir tutum sergilemesi Rusya tarafından tepki ile karşılanmıştır. Tüm bu olaylar üzerine Moskova, Ukrayna'nın doğusundaki ve Kırım'daki Rus yanlılarını desteklemiş ve çatışmalar yaşanmasına yol açmıştır. Rusya hükümeti Ukrayna Krizi başladığından beri bunun Batılı devletler ve ABD tarafından kışkırtıldığını ve mevcut hükümete karşı Batının desteklediği bir eylem olarak gördüğünü belirtmiştir. ABD'nin Ukrayna büyükelçisinin sızan telefon görüşmelerinde aslında Putin'in haklı olduğu görülmektedir. Bu telefon görüşmesinde Yanukoviç iktidarının devrilmesinin ve yerine Batı yanlısı bir iktidarın gelmesinin savunulduğu göze çarpmaktadır (Mearsheimer 2014: 5). Batı yanlısı Poroşenko hükümetinin gelmesi ve AB ile Ortaklık Antlaşmasının imzalanması üzerine Rusya'nın tepkisi yeni bir uluslararası kriz meydana getirmiştir. Rusya irredentist ${ }^{2}$ bir politika uygulayarak Kırım'daki Rus etnik varlığını ileri sürerek, Kırım'ı işgal etmiş ve daha sonra bir referandumla Kırım'ı topraklarına katmıştır.

Rusya tarafından Kırım'ın ilhak edilmesi Karadeniz jeopolitiğinde önemli değişimler ortaya çıkardı. Kırım'ın ilhakı ile birlikte ilk olarak Rusya'nın Karadeniz'deki karasuları ve deniz yetki alanları

\footnotetext{
${ }^{2}$ İrredantizm: Dil, din, soy ve kültür birlikteliği olduğu halde herhangi bir devletin sınırları dışında yer alan halkı ile birleşme fikridir. Genelde karşımıza yabancı ülkelerin topraklarında soydaşlarını bahane eden devletin yayılma siyaseti olarak kullanmasıyla karşımıza çıkmaktadır.
} 
genişlemiş oldu. Rusya hem enerji kaynakları geçiş hatlarına hem de Karadeniz'in muhtemel enerji kaynaklarına sahip olabilecek bir konum elde etti.

Rusya devlet başkanı Putin, Kırım'ın Rusya'ya katılım antlaşmalarının imzalandığı gün yaptığ1 açıklamada ABD önderliğindeki Batı dünyasına ve NATO'ya meydan okumuştur. “Ukrayna’yı bilerek kışkırtanlar ve iç karışıklığa sürükleyenler bulunmakta. Ukrayna'nın bölünmesini istememekteyiz ve NATO askerlerinin Kırım'da, Sivastopol'da hak sahibi olmasını ve Karadeniz'de NATO askerlerinin Rus donanmasını karşılamasına izin vermeyeceğiz...” (Address by President of the Russian Federation 2014: Mart 18)

Kırım Ukrayna'nın güneyinde Karadeniz'e doğru yarımada şeklinde uzanan Ukrayna'ya bağlı özerk cumhuriyettir. Nüfusu 2 milyon civarında olan bölgenin yaklaşık yüzde 60'1 Rus yüzde 25'i Ukraynalı, yüzde 13'ü de Tatar etnisitesine aittir. ${ }^{3}$

Ukrayna krizi ile birlikte Kırım'ın Rusya'ya bağlanması ile ilgili olarak Putin bir diğer açıklamasında, Kırım'ın Ruslar açısından önemini çarpıcı şekilde ifade etmiştir. "Kırım bizim için stratejik önem taşıyor. Yahudiler için Kudüs'teki tapınak tepesinin olduğu gibi bizim için kutsal değeri var.”( Putin Batı'ya rest çekti 2014: Aralık 5)

Rusya'nın Ukrayna ve Kırım'1 ABD ve ABD önderliğindeki Batılılara kaybetmesi demek Karadeniz'deki hâkimiyeti kaybetmesi demek bu da Rusya için beka sorununun gündeme gelmesi demek olacaktır. Ukrayna'da Batı yanlısı bir hükümet kurulması ve Ukrayna'nın Batılı kurumlara katılması Rusya'nın hemen yanı başında bir Batı kalesi ile karşı karşıya kalmasına neden olacaktı (Mearsheimer 2014: 6). Kırımda bulunan Sivastopol üssü 2. Katerina döneminden beri Rus donanmasının Karadeniz'deki en stratejik konumudur. Rusya'nın Soğuk Savaş sonrası girdiği bunalım döneminden sonra tekrardan uluslararası sistemdeki etkin güçlerden biri olması yakın çevresinden geçmektedir ve yakın çevresinin kendi hâkimiyeti altından kaybolması uzun vadede Rusya'yı siyasi, ekonomik ve güvenlik anlamında darboğaza sokabilecektir. Rusya için NATO'nun Karadeniz'e doğru genişlemesi Rusya'nın yaşamsal çıkar alanına müdahale anlamına gelecektir ve büyük bir beka sorunu ile karşı karşıya kalacaktır. Kırım'ın işgali ile birlikte Rusya Karadeniz'deki güvenliğini sağlamlaştırmış ve hem Ukrayna'ya hem de Ukrayna üzerinden $A B D$ ve Batı dünyasına mesaj vermiştir. Yakın çevresinde kendisinden başka herhangi bir devletin etkinlik kurmasına izin vermeyeceğini ve gerekirse güç kullanacağını 2008 Gürcistan Savaşı, Ukrayna krizi ve Kırım işgalleri ile tüm dünyaya ilan etmiştir.

Kırım'ın Rusya tarafından ilhakından itibaren $A B D$ ve $A B$ üyesi ülkeler Rusya'ya yönelik öncelikle diplomatik izolasyon kararını, sonrasında ise ekonomik yaptırımları hayata geçirmiştir. Bununla birlikte gerek Kırım gelişmesiyle beraber sürekli kınama metni yayınlayan NATO’nun

\footnotetext{
3 “About Number And Composition Population Of Autonomous Republıc Of Crimea By Data All-Ukrainian Population Census", http://2001ukrcensus.gov.ua/eng/results/general/nationality/Crimea (E.t: 28.10.2017)
} 
demeçleri, gerek Kremlin'den gelen tonu yüksek açıklamalar dikkate alındığında (Sarıkaya 2015: 190), Ukrayna'daki çatışmanın bir iç sorun olmaktansa uluslararası bir kriz olduğunu gözler önüne sürmekteydi.

$A B D$ ve $A B D$ önderliğinde Batı dünyası yani $A B$ tarafından Rusya’ya karşı yaptırım kararları sürekli olarak genişletilmiştir. Temmuz 2014'te ABD tarafından Rusya'ya sağlanan ihracat kredisinin askıya alındığı açıklanmış ve Rus ekonomisinin büyük bir darbe alması beklenmiştir. Pek çok Rus devlet adamı ve iş adamının Avrupa'ya ve ABD’ye girişi yasaklanırken mal varlıkları da dondurulmuştur (Özel 2015: 80-84). Fakat Rusya'nın Ukrayna krizini desteklemesi ve Kırım'1 ilhakı üzerine ABD ve Batılı ülkeler ekonomik anlamda bazı yaptırımlar yapsa da AB-Rusya arasındaki ekonomik ilişkilerde Almanya gibi devletler ciddi hasar görmeye başladıklarından ve bu hasarın boyutunun artacağı endişesiyle sürekli olarak yaptırımların arttırılmasına karşı çıkmaya başlamışlardır (Mearsheimer 2014: 9).

ABD açısından devam etmekte olan Suriye krizi, Irak ve Afganistan'da hala sürmekte olan toplumsal dönüşüm süreçleri ve daha başka önceliklerinin de olması ABD’nin bu krizde yeterli etkiyi gösterememesine sebep olmuştur.

Rusya açısından Ukrayna Krizi Soğuk Savaş sonrası uluslararası sistemin tek kutuplu düzenine bir meydan okuma olarak algılanmış ve Rusya bu süreç içerisinde uluslararası sistemin tek kutuplu düzen olmadığını ve dünyadaki hegemonik ABD gücüne karşı Rusya’nın da var olduğu mesajını vermeye çalışmıştır.

\section{Suriye Krizi Çerçevesinde Rusya ve ABD İlişkileri}

2010 yılında Tunus'ta başlayan ve daha sonra tüm Ortadoğu'ya yayılmaya başlayan demokratikleşme hareketinin, bilinen adıyla "Arap Baharı" zincirinin son halkasını Suriye oluşturmuştur. Tunus ve Libya' da rejim değişikliği, Mısır'da ilk olarak demokratik bir yönetim ardından askeri darbeyle vesayete geçiş denemesinin sonrasında Mart 2011'de Suriye'de Arap Baharının dalgası olarak başlayan olaylar, zamanla iç savaşa dönüşmüştür (Özçelik 2016: 2). Suriye'de yaşanan kriz, 2011 Mart'ta Esad yönetimindeki rejim ve muhalif güçler arasındaki çatışmalarla başladı ve günümüzde hala devam etmektedir. Yaklaşık 6 yıldır devam eden krizin vahim sonuçları olarak on binlerce kişi hayatını kaybetmiş, evsiz kalmış ya da ülkedeki şiddet ortamından kaçarak Türkiye, Irak ve Lübnan gibi komşu ülkelere sığınmak zorunda kalmıştır. Mart 2011'de Esad rejimine karşı başlayan gösterilerin rejim tarafından sert müdahalelerle önlenmeye çalışılması ve askeri müdahaleye başvurulması ile ülke kısa süre içerisinde kaosa sürüklenmiş ve halk hareketlerinin uluslararası bir krize dönüşmesinin yolu açılmıştır (Ulutaş ve vd. 2015: 8).

Arap Baharı Mısır, Libya, Tunus, Cezayir, Ürdün gibi ülkelerde kısa sürede sonuçlanırken, Suriye'de başlayan hareketlenme günümüzde hala devam etmektedir. Suriye krizinin 2011 Mart'indan beri devam etmesinin en temel nedeni krizin bir süre sonra uluslararası bir krize dönüşmesi ve bu 
noktada bölgesel ve küresel aktörlerin yanı sıra birçok terörist grubunda krize dâhil olmasıdır. Suriye Ortadoğu'da özellikle Amerikan-İsrail hâkimiyetine karşı Tahran-Şam-Hizbullah ayağının önemli bir parçasıdır (Deniz 2013: 319). Krizin uluslararası bir soruna dönüşmesi ile birlikte aktörler arasındaki rekabet Suriye'yi bir kan gölüne dönüştürmüştür. Bu süreç içerisinde Rusya, Suriye devlet başkanı Esad'ın arkasında bir tavır alırken, ABD yönetimi ise Esad'sız bir çözümün olması gerektiğini savunmuştur. ABD bu dönemde Esad'ın derhal gitmesi gerektiğine vurgu yaparken Rusya ise ABD'nin bu tezine karşıllk sorunun bir iç kriz olduğu ve müdahale edilmemesi gerektiği görüşü üstünde durmuştur. Taraflar açısından aynı dönemde hem Ukrayna Krizi yaşanması hem de Suriye'de karşı karşıya gelinmesi tekrardan bir Soğuk Savaş mı yaşandığı sorusunun uluslararası sistemin gündemine gelmesine neden olmuştur.

Suriye Krizini bu iki ülke açısından analiz etmeden önce bu iki ülke açısından Suriye politikalarının ve Suriye'nin öneminin belirtilmesi kriz esnasında yaşanılanları daha iyi anlamamızı sağlayacaktır.

\section{Suriye Krizi Çerçevesinde ABD-Rusya Rekabeti}

\section{Obama'nın Ulusal Güvenlik Stratejisi ve Suriye'nin ABD Açısından Önemi}

ABD 11 Eylül saldırıları ile birlikte Ortadoğu'da düzeni sağlama adına harekete geçmiştir. $\mathrm{Bu}$ doğrultuda gerçekleşen Afganistan ve peşinden gelen Irak işgalleri ABD açısından beklenildiği gibi gerçekleşmemiştir. ABD kısa sürede düzeni kurmayı amaçladığı bu işgallerde adeta bataklığa saplanıp kalmış ve bu işgallerin ABD’ye maliyeti yüksek olmuştur. ABD, 11 Eylül sonrası Bush’un teröre karş1 savaş doktrinini benimsemiş fakat bu yaklaşım Obama'nın gelmesiyle birlikte etkinliğini kaybetmeye başlamıştır. Obama'nın başkan adaylığını açıklamasından itibaren en önemli sloganlarını "ümit" ve “değişim” oluşturmuştur (Yalçın 2016: 27).

Obama'nın iktidara gelmesiyle birlikte Ortadoğu üzerinde temel amaç Irak ve Afganistan'dan çekilmekti ve gelir gelmez bu yönde adımlar atmaya başladı. ABD'nin dünya siyasetinde 11 Eylül ile birlikte oluşmuş olan olumsuz algısını özellikle sert tutumunu ve tek taraflı müdahaleci algısını değiştirmek amaçlanmış ve daha çok, çok taraflı ve sorunlara uluslararası kurumlar aracılığıyla müdahil olmaya çalışan bir Amerika ortaya çıkarmak için çaba sarf edilmiştir (Yalçın 2015: 58-61).

Genel olarak retrenchment(mevzilenme) olarak adlandırılan Obama'nın güvenlik stratejisi bir bakıma 1823 Monroe Doktrini'ne benzetilebilir. Kısa olarak özüne kapanma ve kendini dış dünyadan izole etme olarak adlandırılabilecek olan Monroe Doktrini ${ }^{4}$ Obama'nın başkanlık dönemi stratejileri ile benzerlik göstermektedir. Obama'nın güvenlik stratejisini genel olarak ABD’nin uluslararası politikaya gerekmediği sürece ve olabildiğince az olmak kaydıyla müdahil olması ve sahaya Amerikan askerlerinin indirilmesinden kaçınılması oluşturmaktadır. Obama Irak ve Afganistan işgallerinin ABD açısından

\footnotetext{
${ }^{4}$ Ayrıntılı bilgi için; Armaoğlu, Fahri, 19. Yüzyıl Siyasi Tarih, 1789-1914, İstanbul: Timaş Yayınları, s. 688692.
} 
son derece maliyetli olduğunu görmüştür. Aynı zamanda dünyada $\mathrm{ABD}$ dışında güç merkezlerinin oluşması ve uluslararası sistemde yeni büyük güçlerin ortaya çıkmaya başlaması, ABD'nin uluslararası sistemdeki rolünü tehdit eder nitelik alması endişesiyle ABD'yi yeni arayışlar içerisine itmiştir. $\mathrm{Bu}$ noktada Obama mevzilenme stratejisi ile ABD'nin öncelikle kendi gücünü koruması ve aynı zamanda arttırmasını amaçlamıştır.

Uluslararası sisteme baktığımızda ekonomik veriler göz önüne alındığında ABD’yi oldukça zorlamaya başlayan ve ekonomik gücünün yükselmesiyle birlikte Asya Pasifik'te hegemon olmaya başlamış bir Çin karşımıza çıkmaktadır. Ayrıca Soğuk Savaş sonrası girdiği bunalımdan sıyrılan ve 2008 yılında Gürcistan müdahalesi, Ukrayna Krizi, Kırım'ın ilhakı ve Suriye'deki aktif konumuyla ABD’nin tek kutuplu düzenine meydan okuyan bir Rusya karşımıza çıkmaktadır.

Uluslararası sistemde ortaya çıkan yeni güç odakları karşısında ABD’nin yeni maceralara atılması, bunların maliyeti düşünüldüğünde aslında Obama, Suriye'deki krizi tek başına üstlenmek yerine birçok aktörün bölgede maliyet yüklenmesini ve ABD'nin de soruna uluslararası kurumlarla müdahil olmasını hedefledi. Bu sayede ABD yönetimi içeride güç toplamaya devam edecek ve krizi uluslararası kurumlar altından kontrol edecekti.

Amerikan dış politikasının genel olarak Ortadoğu hedeflerini Batı yanlısı 1lımlı hükümetlerin kurulması, enerji güvenliğinin sağlanması, İsrail'in güvenliğinin sağlanması ve bu doğrultuda İran önderliğindeki Şii ekseninin çevrelenmesi ve bölgede ABD dışında herhangi bir gücün hâkimiyet kurmasının önlenmesi olarak sıralayabiliriz. Bölgede 1979 İran Devrimi ile birlikte, devrimin bölge ülkelerine ihraç edilmeye çalışılması ve bu noktada Suriye ve İran'ın müttefikliği, bölgede bu iki ülkenin Hizbullah'a destek vermesi hem ABD'nin bölgedeki hegemonyasını hem de İsrail'in güvenliğini tehdit eder nitelikteydi.

Ayrıca bölgede Suriye yönetiminin devrilmesi ve yerine Batı yanlısı bir iktidarın gelmesiyle birlikte Rusya'nın bölgedeki etkinliği tamamen azaltılacaktı. Aynı zamanda Rusya'nın Akdeniz’e çıkış noktasını oluşturan Laskiye limanının kapatılması Rusya'yı Akdeniz'in dışına itecekti. Aynı zamanda Rus hidrokarbon kaynaklarına alternatif rotalar oluşturulabilecek ve bu sayede ekonomisi yüksek oranlarda hidrokarbon kaynaklarının ihracına bağımlı Rusya'ya önemli bir darbe daha vurulmuş olacakt1.

\section{Rusya Açısından Suriye'nin Önemi}

Rusya Soğuk Savaş'ın sona ermesi ile Sovyetler Birliği’nin en önemli halefi olarak ortaya çıkmıştı. Ekonomik anlamda toparlanmaya başlamasıyla birlikte özellikle yakın çevresinde etkili olmaya başlayan Rusya yukarıda da belirtildiği gibi Gürcistan, Ukrayna ve Suriye Krizlerini ABD’nin tek kutuplu düzenine meydan okuma ve uluslararası arenaya bende varım mesajını verebilmenin firsatı olarak görmüştür. Bu doğrultuda aslında meydan okumanın en önemli sinyalini Rusya devlet başkanı Putin'in 2007 yılında Münih Güvenlik Konferansı'ndaki konuşması oluşturmuştur. Putin bu 
konuşmasında adeta ABD'ye ve ABD'nin önderliğindeki uluslararası sisteme başkaldırmıştır (Speech and the Following, 2007: Şubat 10).

Rusya 2010 yılında başlayan Arap Baharı'nın Tunus, Mısır gibi ülkelerde ortaya çıkan iktidar değişikliklerine karşı herhangi bir tepkide bulunmamıştı. Özellikle silah ve ekonomik anlamda iyi ilişkilerde olduğu Libya'ya sıçrayan halk hareketlerine karşı aktif tavır takınmayan Rusya Kaddafi'nin devrilmesini kabullenmek zorunda kalmıştır (Erşen 2016: 153-155). Fakat bu Rusya için örnek teşkil etmiş ve Suriye Krizi başladığı andan itibaren krize aktif olarak müdahil olmuştur.

Rusya, Suriye'de yaşanan olaylara Suriye ile uzun yıllardır süregelen iyi ilişkilerinin sahip olduğu karşılıklı faydalar çerçevesinde yaklaşmıştır. Rusya Arap Baharı'nın bölgede Batı yanlısı rejimler kurmak için bir oyun olduğunu savunmuş ve bu doğrultuda bölgedeki etkinliğinin kaybolmasından endişe etmiştir (Yazıcı 2012: 40-42).

Ortadoğu Soğuk Savaş dönemi boyunca iki blok liderinin çekişmelerine sahne olmuştu. $\mathrm{Bu}$ doğrultuda Sovyetler Birliği ile iyi ilişkiler geliştirmiş olan Suriye, Soğuk Savaş sonrası halef konumundaki Rusya ile de iyi ilişkilere sahip olmuştur. Rusya açısından Suriye, bölgede İran ile birlikte en önemli ülkeler arasında yer almaktaydı. Suriye'de bulunan ve Akdeniz'e çıkış kapısı olmakla kalmayıp Rusya'nın bölgede nüfuz kurma ve bunu devam ettirebilmesi açısından son derece önemli bir yere sahip olan Tarsus üssü ve Laskiye limanı Rusya açısından son derece önemlidir. Rusya’nın bu üsleri ve Suriye'yi kaybetmesi demek Doğu Akdeniz'deki ve Ortadoğu'daki nüfuzunu kaybetmek demektir. Bu da Sovyetler sonrası küresel iddiasını sürdürmek isteyen Rusya için bu iddiasından vazgeçmek anlamına gelecektir. Suriye'nin Batılı devletler tarafından ele geçirilmesi daha doğrusu Batı yanlısı bir hükümetin gelmesi Ortadoğu bölgesinin tamamen ABD nüfuz bölgesi olmasına yol açacaktır.

Ayrıca Suriye Rusya açısından önemli bir silah pazarıdır. Suriye silahlı kuvvetlerinin kriz çıkmadan önceki dönemde sahip olduğu silahların yaklaşık \%90'nının Rus yapımı olması ve 2005-2011 yılları arasında Rusya'dan yaklaşık 25 milyar \$'lık silah satın alması Rusya'nın silah ticaretinde Suriye'nin ne kadar önemli bir yer tuttuğunu göstermektedir. Suriye’yi ABD’ye kaptırmak Rusya açısından önemli silah pazarını kaybetmek olacaktır (Deniz 2013: 323-324). Suriye'nin ABD tarafina çekilmesiyle birlikte Rusya açısından bölgedeki en önemli müttefiki olan İran yalnızlaşacak ve çevrelenecektir. Bu da İran üzerinden Rusya'nın da yakın çevresinin tehdit altında olmasına neden olacaktır.

Her şeyden önemlisi Rusya açısından Suriye krizi, Soğuk Savaş sonrası uluslararası sistemde kendisinin tekrardan var olduğunu ve artık yeni sistemin tek kutuplu olmadığını ispatlamak açısından da son derece önem teşkil etmektedir.

\section{Krizin Gelişimi ve ABD Rusya Rekabeti}

Ortadoğu coğrafyası tarihin her döneminde büyük güçlerin ilgi gösterdiği ve rekabet ettiği bir coğrafya olarak karşımıza çıkmaktadır. Suriye'deki reform istekleri ve demokratikleşme hareketlerine 
rejimin verdiği sert karşıllk bir anda krize bölgesel ve küresel birçok aktörü müdahil etti. Ukrayna Krizi’nde de karşımıza çıktığı gibi ABD önderliğindeki Batı daha müdahaleci ve Esad yönetiminin sona ermesini isteyen bir tavır tutunurken, Rusya ve müttefiki Çin Suriye'ye gerçekleştirilebilecek her türlü müdahaleye karşı bir tavır tutundular (Tepeciklioğlu Ali ve Tepeciklioğlu Elem 2015: 174-175). Bu doğrultuda özellikle bölgede dengeleri değiştirebilecek ve nüfuzu ABD’ye kaptırabilecekleri BM kararlarını sürekli veto etmişlerdir.

İlk olarak 2011 yılında rejim tarafindan gerçekleştirilen sert eylemlere karşı BM tarafından alınmak istenilen Suriye'ye karşı daha sert adımlar atılmasını ve gerektiğinde yaptırımlara maruz kalabileceği karar tasarısı Rusya ve Çin tarafından veto edilmiştir. Rusya temel olarak bu krizin Suriye'nin bir iç sorunu olduğu ve olası karar tasarısının geçmesi durumunda Suriye'ye karşı müdahalenin olabileceği gerekçesiyle kararı veto etmiştir (Suriye’ye BM baskısını, 2011: Ekim 5).

2012 yılının Şubat ayında BM Güvenlik Konseyi tarafından Suriye'deki şiddetin derhal sona ermesi çağrısında bulunan ve Suriye rejimi tarafından yapılan insan hakları ihlallerini kınayan karar tasarısı yine Rusya ve Çin'in vetosu nedeniyle reddedilmiştir. Rusya bu karar tasarısını, tasarının tek tarafı suçladığını, dengeli olmadığını ve Suriye'deki gerçekleri yansıtmadığını iddia ederek veto ettiğini belirtmiştir (Suriye Tasarısına Rusya, 2012: Şubat 4).

BM Güvelik Konseyindeki Rusya ve Çin' in bir diğer vetosu 19 Temmuz 2012'de gerçekleşti. Bu iki ülkenin 9 ay gibi kısa sürede üçüncü kez Suriye konusundaki vetoları olmuştur. Bu karar tasarısı Suriye rejiminin 10 gün içinde ağır silahların kullanımına son vermemesi halinde yaptırımı içermekteydi (Rusya'yla Çin'den üçüncü veto, 2012: Temmuz 19).

ABD ve Rusya arasındaki Suriye rekabetine baktığımızda Rusya her firsatta Suriye'nin arkasında durduğunu BM'de bu ülke aleyhine gerçekleştirilen kararları veto ederek göstermiştir. Aslında Rusya'nın her firsatta Suriye'yi desteklemesi, Batılı aktörler tarafindan gerçekleştirilebilecek tek taraflı müdahaleye karşı olduğunu ve krizin çözümünde Rusya ile uzlaşılmadan sorunun çözülemeyeceğinin mesajıydı.

Bu süreç içerisinde Obama yönetimi tek taraflı müdahaleden kaçınmayı ve uluslararası kurumlar aracılığıyla krize müdahil olmayı tercih ederken, krize birçok aktörün dâhil olmasını sorun etmedi

Hatta krizin bir yerden sonra kilitlenmesi ve bölgenin ve bölgedeki aktörlerin fazla maliyetler yüklenmeleri ABD yönetimini memnun etti. Obama'nın iktidara gelmesi ile tekrardan güç toplama adına mevzilenme politikası izleyen $\mathrm{ABD}$ tarafindan bölgenin kaosa sürüklenmesi ve kaosun statükoya dönüşmesi bir noktadan sonra kazançlı olmaya başlayabilirdi. Çünkü her ne kadar krizin ilk başladığı dönemlerde ABD yönetimi tarafından Esad'ın devrilmesi görüşü hâkimken krizin süreç içerisindeki dönüşümü artık Esad'siz bir Suriye'nin ABD açısından daha olumsuz sonuçlara yol açılabileceği şeklinde değerlendirilmekteydi. 
ABD yönetiminin krize direkt müdahil olmamasının önemli bir diğer nedeni de kamuoyu baskısıydı. ABD kamuoyu öngörülemez sonuçlar doğurabilecek müdahalelerden kesinlikle kaçınılması yönünde tavır sahibiydi. Halk için Afganistan ve Irak işgallerinin yarattığı travmalar hala tazeydi ve aynısının Suriye'de yaşanması istenilmemekteydi.

Obama'nın 2012 yılında Suriye'de kırmızı çizgilerinin kimyasal silah kullanımı olduğunu açıklaması üzerinden henüz 1 yıl geçmişken, 2013 yılında rejim tarafından kullanılan kimyasal silahlarla birlikte tüm dünyanın gözü ABD’nin müdahalesine odaklanmıştı. Bu noktada Rusya Esad rejimine karş1 yapılacak herhangi bir müdahaleyi önleyebilmek adına arabuluculuk rolü üstlendi. Rusya'nın önerisi gelinceye kadar ABD rejim birliklerine hava saldırıları düzenlemek üzereydi. Rusya'nın arabuluculuğunda ABD'nin de onayıyla birlikte BM destekli antlaşma ile birlikte ABD müdahale etmekten vazgeçti. Rusya'nın arabuluculuk rolü Suriye krizinde aldığı rolün daha değerli hale gelmesini sağlamıştı. Bu anlaşmayla birlikte Suriye'den kimyasal silahların çıkarılması ve imalathanelerin kapatılması konusunda ortak karar alındı (Suriye: Kimyasal silah, 2014: Ağustos 21).

ABD Suriye krizinin başlarında Esad'sız bir değişim yanında tavır alırken, Suriye krizinde bölgede birçok devlet dışı aktörlerin yer almasıyla bu tavrında değişikliğe gitti. Özellikle 2014 yılından itibaren bölgede çok aktif rol almaya başlayan DAEŞ terör örgütü ile birlikte süreç Esad'siz bir Suriye'de işlerin daha da karışabileceği ve böylece krizin daha önlenemez durumlar alabileceği yönündeki tavıra doğru yol aldı (Oytun 2013: 89-91). ABD, DAEŞ'in yoğun olarak bölgede faaliyete geçmesi ile birlikte hedefini Suriye'de demokratikleşmeden DAEŞ'in temizlenmesine dönüştürdü. Bu süreç aslında Rusya'nın da bölgede tam anlamıyla rol oynamaya başlamasını sağladı. DAEŞ'in bölgede rol alması ile birlikte Rusya'nın bölgeye girmesi ve operasyonlar düzenlenmesi ABD’nin işine gelmekteydi. Hem Rusya Suriye'de önemli bir maliyetin altına girmekteydi hem de DAEŞ'in temizlenmesi konusunda ABD herhangi bir maliyete girmeksizin bu Rusya tarafindan gerçekleştiriliyordu. Burada ABD açısından en önemli dezavantaj Rusya'nın bölgede aktif rol almaya başlamasıydı. Çünkü ABD’nin krizin ilk yıllarındaki temel amacı olan Esad rejiminin değişmesi ihtimali Rusya'nın sahaya girmesiyle birlikte ortadan kalkmıştı. Ayrıca uluslararası sistemde Soğuk Savaş sonrası tekrardan sistemde büyük bir güç olarak yer almak isteyen Rusya'nın eline büyük bir firsat geçmekteydi. Rusya krizin çözümünde rol alacak en önemli aktörlerden biri haline gelmişti ve bu ABD’nin istediği dönüşümü oluşturmasının önünde engel oluşturmaktaydı.

Rusya'nın 2016 yılı başlarında Halep'i bombalaması üzerine ABD ve Rusya arasındaki ilişkiler gerildi. ABD Başkanı Obama'nın DAEŞ ile Mücadele Özel Temsilcisi McGurk Rusya’nın Halep’ten Türkiye'ye uzanan insani koridoru vurduğunu ve bunun bir insani kriz ortaya çıkardığını belirtti (Rusların Halep'i bombalaması, 2016: Şubat 24). Rusya ise savunma bakanlığı aracılığıyla yaptığı açıklamada, Halep'i bombalayan uçakların Rusya'ya ya değil ABD'ye ait olduğunu belirtti (Rusya: Halep'i biz değil, 2016: Şubat 11). 
ABD ve Rusya arasındaki ilişkiler Rusya'nın sahada gerçekleştirdiği operasyonlarla ara ara gerilse de 2016 Şubat'ın da ABD ve Rusya önderliğinde BM destekli ilk geniş çaplı ateşkes anlaşmasına varıldı. Geçici çatışmazlık anlaşması Suriye yönetimini ve birçok muhalif grubu kapsamaktaydı. $\mathrm{Bu}$ anlaşmaya birlikte DAEŞ ve El Kaide'ye bağlı Nusra Cephesi anlaşmanın dışında tutuldu. Ateşkes ile birlikte kuşatma altındaki sivillere yardım ulaştırılması hedeflendi. Ayrıca DAEŞ ve Nusra gibi örgütlerin Suriye'den temizlenmesi hedeflendi. BM kararında acil yardıma ihtiyacı olan yaklaşık 30 bölge belirlendi ve öncelikle yardımların bu bölgelere gerçekleştirilmesi hedeflendi (Suriye'de ateşkes başladı, 2016: Şubat 27).

2016 yılında ABD'de başkanlık seçimlerinin yaşanması ABD'nin bu dönemde Suriye krizine karşı biraz geri planda kalmasına neden oldu. Özellikle bu dönemde Rusya'nın ön plana çıktı̆̆ krizde Rusya liderliğinde Türkiye ve İran'ın da katılımıyla Kazakistan'ın başkenti Astana'da gerçekleşen zirveler krizin çözümü ile ilgili planlar oluşturmaya başladı ve ABD bu süreçte krizin çözümünde geri planda kaldı.

2016 yılındaki başkanlık yarışından galip çıkan Donald Trump göreve geldiği dönemde yaptığ1 ilk açıklamalarda genellikle Obama yönetiminin krizde aldığı pasif rolü eleştiren bir tavır takındı. Obama yönetiminin Suriye'de Esad'ın ve Rusya'nı önünü kesmemekle suçlayan Trump Suriye'de önceliğinin DAEŞ’i temizlemek olduğunu vurguladı. Trump başkan seçildikten birkaç gün sonra Wall Street Journal'a verdiği röportajla önceliğinin DAEŞ ile savaşmak olduğunu açıkça ortaya koyuyordu. “Siz Suriye ile savaşıyorsunuz. Suriye IŞíD ile savaşıyor ve siz de IŞİD’den kurtulmak zorundasınız. ABD'nin Suriye'deki asıl amacı IŞíD ile mücadele olmalı. Esed'i hiç sevmesem de rejimini desteklemek radikalleri durdurmak için en iyi yol.” (Obama’yı eleştiren Trump, 2017: Nisan 5)

Trump ile birlikte Suriye politikasındaki dönüşümü daha net ortaya koymaya başlayan ABD DAEŞ ile mücadelede Rusya ile iş birliği konusunda daha 1lımlı olmaya başladı. Trump'ın gelmesiyle birlikte başlayan Rusya ve ABD arasındaki iş birliği fikri 2017 Temmuz'da Hamburg'da düzenlenen G 20 Zirvesinde ilk somut gelişmeleri ortaya çıkardı. İlk kez yüze yüze görüşme gerçekleştiren Putin ve Trump ikilisi Suriye'nin güneybatısında Ürdün'ün de katılımıyla çatışmasızlık anlaşması konusunda ortak noktada buluştular (Trump ve Putin, 2017: Temmuz 7).

Trump'ın başkanlığa gelmesi sonrası sahada Rusya ve ABD arasında Hamburg' da başlayan iş birliği DAEŞ'in Suriye'den temizlenmesi açısından son derece önemliydi. Bu süreçte krizin ilk y1llarından itibaren Esad rejiminin destekçisi olan Rusya krize müdahil olduğu dönemden itibaren her geçen gün krizdeki etkinliğini arttırmış ve böylece Esad rejiminin yıkılmasının önüne geçmişti. Trump ile birlikte ABD'nin Esad'ın gitmesi yönündeki tavrının da değişmesiyle birlikte kriz Rusya'nın istediği şekilde seyretmekteydi. Rusya hem yakın ilişkilerde bulunduğu rejimin varlığını korumuş hem de Suriye ve Ortadoğu'daki varlığını pekiştirmişti. 
Trump ve Putin 2017 Kasım'ın da Vietnam'daki APEC zirvesinde Suriye ile ilgili önemli görüşmeler gerçekleştirdi ve bu doğrultuda Suriye'de iş birliği konusu vurgulandı. İki liderin ortak açıklamasında özellikle Suriye'de DAEŞ'in yenilgiye uğratılması konusundaki kararlılıkları teyit edildi. İki lider tarafından ayrıca BM Güvenlik Konseyi’nin 2254 sayılı karar uygun olarak Suriye'nin egemenliği, bağımsızlığı, birliği, toprak bütünlüğü ve laik niteliğine bağlllık teyit edildi. Ayrıca açıklamada Suriye'deki tüm taraflara Cenevre'deki siyasi sürece aktif olarak katılma çağrısı da yer aldı. Anlaşmada Suriye'deki çatışmanın askeri çözümü olmadığını çözümün siyasi olarak gerçekleştirilmesinin gerekliliği de vurgulandı (Putin ve Trump’tan, 2017: Kasım 11).

Özellikle DAEŞ'in sahada aktif olarak ortaya çıkması ve bölgede büyük bir tehdit oluşturması sonrası ABD ve Rusya arasında bir iş birliğinin öne çıktığı görülmektedir. Trump'ın ABD'de başkanlığa gelmesiyle birlikte bu iki devlet arasındaki iş birliği daha güçlü bir şekilde ortaya çıkmıştır.

\section{Sonuç}

Soğuk Savaş sona ermiş, Sovyetler Birliği dağılmış ve Rusya büyük bir çöküntü içerisine girmişti. Uluslararası sistem çift kutuplu düzenden ABD'nin hegemonyası altında tek kutuplu bir düzene dönüşmüştü. ABD uluslararası sistemi ve yeni dünya düzenini kendi çıkarları doğrultusunda dizayn etmekteydi. Ukrayna ve Suriye Krizleri, Rusya'nın Soğuk Savaş sonrası ABD’nin oluşturduğu yeni dünya düzenine karşı en büyük meydan okuma firsatlarını oluşturdu. Özellikle girdiği bunalımdan hidrokarbon kaynakları sayesinde kurtulan Rusya ilk olarak Gürcistan müdahalesi ile uluslararası arenaya mesaj verirken, Ukrayna Krizinde tüm dünyanın gözü önünde Kırım’1 ilhak etti. ABD’nin 11 Eylül sonrası gerçekleştirdiği Afganistan ve Irak müdahalelerinde katlandığı maliyetler, Ukrayna ve Suriye'de Rusya karşısında silahlı mücadeleye girilmesinin engelini oluşturdu.

Rusya, Sovyetler Birliği’nin dağılmasının ardından eski gücüne kavuşabilmek adına yakın çevresine özel bir önem vermiştir. Bu bölgede ABD önderliğindeki Batı'nın faaliyetlerine karşı hep endişeli yaklaşmış ve bölgede tekrardan hâkim güç olmayı istemiştir. ABD ise Rusya'nın yakın çevresinde tekrardan hakim güç olmasının yeni bir potansiyel tehdit ve yeni riskler ortaya çıkaracağından, Rusya'nın bölgede hakim güç olmasını engelleyecek politikaları takip etmeye çalışmıştır.

Ukrayna jeopolitiği Batı'ya açılan bir kapı olma ve hidrokarbon kaynaklarının geçiş güzergâhında bulunması nedeniyle Rusya açısından son derece önemlidir. Bu nedenle Ukrayna'nın Batı ile entegre olma ihtimali, Rusya'nın büyük güç iddiasını kaybetmesi ihtimalini doğuracağından dolayı Rusya Ukrayna Krizi'ne doğrudan müdahil olmuştur. ABD açısından ise Ukrayna, dünyanın farklı coğrafyalarında kendine tehdit oluşturabilecek potansiyel güçleri engelleme ve Sovyetler Birliği'nin halefi konumundaki Rusya'nın hâkimiyet kurabileceği alanı kısıtlama nedeniyle önem teşkil etmekteydi. Dolayısıyla Ukrayna'da başlayan protestolar ABD’nin ve Rusya'nın güç mücadelesi içerisinde bir krize dönüşmüştür. 
Soğuk Savaş döneminde Sovyetler Birliği ve ABD arasında önemli nüfuz kurma mücadelelerinin yaşandığı Ortadoğu, Soğuk Savaş sonrası dönemde de Rusya'nın tekrardan uluslararası sisteme dâhil olması ile birlikte nüfuz mücadelelerinin tekrardan yaşanmaya başladığı bir coğrafya olarak karşımıza çıkmaktadır.

Suriye, Rusya'nın Soğuk Savaş döneminde olduğu gibi, Soğuk Savaş sonrası dönemde de Ortadoğu'daki varlığının kilit noktasını oluşturmaktaydı. Suriye'de bulunan Tarsus Üssü ve Lazkiye Limanı Rusya'nın Ortadoğu'daki varlığının temelini oluşturmakta ve Akdeniz'e çıkışını sağlamaktadır. ABD açısından ise Suriye İran ile birlikte, Ortadoğu hegemonyasının engelleyici noktaları olarak görülmekteydi. Ayrıca Suriye'deki Rus varlığının ortadan kaldırılması, Rusya'nın Ortadoğu'daki varlığının sonlanması anlamına gelecekti. ABD açısından hegemonyanın güçlendirilmiş şekilde devamı Suriye'nin Batı yanlısı bir şekilde dönüştürülmesinden geçmekteydi. Rusya açısından ise Ortadoğu'daki varlığının sürdürülebilmesi için Suriye, Rusya'nın yörüngesinde kalmaya devam etmeliydi. Tüm bu olgular Suriye Krizi’nin kısa zaman içerisinde iç savaş niteliğinden uluslararası bir krize dönüşmesinin altyapısını oluşturmuştur.

Ukrayna ve Suriye Krizleri uluslararası sistemin yeni bir düzene evirildiğinin en büyük göstergeleri olarak karşımıza çıkmaktadır. Bu iki kriz uluslararası sistemin sadece önemli iki krizi olarak karşımızda yer almamaktadır. Aynı zamanda bu iki kriz uluslararası sistemin yapısının dönüşmesini sağlayan krizler olarak karşımıza çıkmaktadır. Özellikle ABD’nin tek yanlı ve müdahaleci politikalarının artık çok muhtemel olmadığı ve Rusya'nın tekrardan uluslararası sistemin önemli bir figürü olduğu bu krizler incelendiğinde daha iyi anlaşılmaktadır. Tüm bu gelişmeler göz önünde bulundurulduğunda uluslararası sistem açısından dünyanın farklı coğrafyalarında önemli güç merkezlerinin oluştuğu görülmektedir. Artık uluslararası sistem ABD’nin kendi çıkarları doğrultusunda şekillendirdiği bir yapı olmaktan çıkmıştır. Rusya bu krizler sırasında oynadığı roller ile birlikte uluslararası sistemde tekrardan var olduğunu göstermiştir. 


\section{Kaynakça}

Brzezınskı, Zbigniew(2005). Büyük Satranç Tahtası. Yelda Türedi (Çev.). Bursa: İnkılâp Kitapevi.

Büyükakıncı, Erhan(2004). Değiş̧en Dünyada Rusya ve Ukrayna. Ankara: Phoenix Yayınevi.

Deniz, Taşkın(2013). "Suriye'nin Durumu, ABD-Rusya Ve Türkiye'nin Tutumu”. Marmara Coğrafya Dergisi. Say1 27.

Erol, Seyfettin Mehmet(2014). "Ukrayna-Kırım Krizi" ya da "İkinci Yalta Süreci". Karadeniz Araştırmaları. Sayı 41.

Erşen, Emre(2016). "Rusya'nın Suriye politikas1: Firsatlar, Riskler Ve Tehditler". Hasan Basri Yalçın(Ed) Ve Burhanettin Duran(Ed). Küresel ve Bölgesel Aktörlerin Suriye Stratejileri. İstanbul: SETA Kitapları.

Keskin, Mustafa(2014). Yakın Çevre Doktrini Bağlamında Rus Dış Politikası: Ukrayna Müdahalesi. Barış Araştırmaları ve Çatışma Çözümleri Dergisi.

Mearsheimer, John(2014). "Why The Ukraine Crisis is The West's Fault". Foreign Affairs. SeptemberOctober.

Mikail, Elnur Hasan(2007). Yeni Çarlar ve Rus Dış Politikası. İstanbul. IQ Yayıncılık.

Oytun Orhan(2013). “ ABD Suriye Konusunda Neyi Bekliyor? “. Ortadoğu Analiz. Cilt:5. sayı:53.

Özçelik, Mehmet(2016). “ABD’nin Dönüşen Suriye Politikası”. Ekonomik Araştırmalar ve Proje Müdürlüğü Bilgi Raporu.

Özel, Suna Merve(2015). Rus Dış Politikasında Ukrayna Krizi ve Türkiye’ye Etkileri. IV. Türkiye Lisansüstü Çalışmaları Kongresi - Bildiriler Kitabı II

Sağlam, Mühdan(2014). "21. Yüzy1lda Küresel Rekabetin Zemini Ukrayna". Ankara Üniversitesi SBF Dergisi. Cilt 69. say1 2.

Sarıkaya, Gül(2015). "Ukrayna Krizinin Karadeniz Güvenliğine Etkileri”. Uluslararası Sistemde Düzen Arayışları Uludağ Üniversitesi Uluslararası İlişkiler Kongresi.

SETA Analiz Raporu. "Sınırları Aşan Kriz Suriye”. Mart 2015. sayı 20

Tepeciklioğlu, Ali Onur ve Tepeciklioğlu, Elem Eyrice(2015). Teoriden Pratiğe: Suriye Krizi ve Uluslararası Toplum. Ankara Üniversitesi SBF Dergisi. Cilt 70. No. 1.

The Ukrainian Crisis A Disputed Past And Present. Harvard IOP Policy Brief. May 2014

Ünal, Mustafa Cem(2011). "Rus Dış Politikasında Enerjinin Rolü ve Ab Enerji Politikasına Etkisi”. Yayımlanmış Yüksek Lisans Tezi. Ankara: Ankara Üniversitesi.

Yalçın, Basri Hasan(2016). “ABD’nin Suriye Stratejisi”. Küresel ve Bölgesel Aktörlerin Suriye Stratejileri. Hasan Basri Yalçın(Ed) ve Burhanettin Duran(Ed). İstanbul: SETA Kitapları.

Yalçın, Basri Hasan(2015). “Obama Stratejisi Ve Ortadoğu”. Akademik Ortadoğu. Cilt 9. sayı 2.

Yazıcı, Amine(2012). "Rusya'nın Suriye Politikası” Akgün, Birol (Der.). Suriye Krizi’nde Bölgesel ve Küresel Aktörler: Perspektifler, Sorunlar ve Çözüm Önerileri. SDE analizi.

Internet Kaynaklart

"About Number And Composition Population Of Autonomous Republic Of Crimea By Data All-Ukrainian Population Census", http://2001ukrcensus.gov.ua/eng/results/ general/nationality/Crimea, (E.t: 28.08.2018)

“Obama'yı eleştiren Trump ne yaptı?”(2017) http://www.aljazeera.com.tr/al-jazeera-ozel/obamayielestiren-trump-ne-yapti, (E.t. 23.08.2018)

"Putin Battya rest çekti" (2014) http://www.cumhuriyet.com.tr/amp/haber/dunya/155445/html, (E.t: 28.09.2018) 
"Putin ve Trump'tan ortak Suriye açıklaması: IŞiD’i yenilgiye uğratma kararlılıkları teyit edildi."(2017) http://tr.sputniknews.com/amp/rusya/201711111030958387-putin-trump-suriyeaciklama/, (E.t. 26.08.2018)

"Rusya'yla Çin'den üçüncü veto" (2012) http://www.aljazeera.com.tr/haber/rusyayla-cinden-ucuncuveto, (E.t. 30.08.2018)

"Suriye: Kimyasal silah saldırısının üzerinden bir yıl geçti”(2014) www.bbc.com/turkce/haberler/ 2014/08/140821_suriye_kimyasal, (E.t. 25.08.2018)

"Rusların Halep'i bombalaması insani kriz yarattı" (2016) http://www.trthaber.com/m/ ?news=ruslarin-halepi-bombalamasi-insani-kriz-yarattı\&news_id=236710\&category_id=1, $\quad$ (E.t. 05.09.2018)

“Rusya: Halep’i biz değil, ABD bombaladı" (2016) http://m.radikal.com.tr/dunya/rusya-halepi-bizdegil-abd-bombaladi-1508861, (E.t. 29.08.2018)

"Suriye Tasarısına Rusya ve Çin'den Veto" (2012) https://www.ntv.com.tr/dunya/suriye-tasarisinarusya-ve-cinden-veto (E.t. 30. 08. 2018)

"Suriye'de ateşkes başladı" (2016) http://www.bbc.com/turkce/haberler/2016/02/ 160227_suriye_ ateskes_basladi, (E.t.30.08.2018)

"Speech and the Following Discussion at the Munich Conference on Security Policy" (2007) http://en.kremlin.ru/events/president/transcripts/24034, (E.t. 30.10.2018)

“Suriye'ye BM baskısını artırma girişimi veto edildi” (2011) http://www.bbc.co.uk/turkce/ haberler/2011/10/111005_syria_un.shtml, (E.t. 29.08.2018)

“Trump ve Putin Suriye'nin güneybatısında ateşkes ilan edilmesi için uzlaşmaya vardı.” (2017) https://www.bbc.com/turkce/amp/haberler-dunya-40530990, (E.t. 26.08.2018) 